This item was submitted to Loughborough's Research Repository by the author.

Items in Figshare are protected by copyright, with all rights reserved, unless otherwise indicated.

\title{
Stakeholder management in PPP projects: external stakeholders' perspective
}

\section{PLEASE CITE THE PUBLISHED VERSION}

https://doi.org/10.1108/BEPAM-02-2018-0048

\section{PUBLISHER}

(C) Emerald

VERSION

AM (Accepted Manuscript)

\section{PUBLISHER STATEMENT}

This work is made available according to the conditions of the Creative Commons Attribution-NonCommercialNoDerivatives 4.0 International (CC BY-NC-ND 4.0) licence. Full details of this licence are available at: https://creativecommons.org/licenses/by-nc-nd/4.0/

\section{LICENCE}

CC BY-NC-ND 4.0

\section{REPOSITORY RECORD}

Amadi, Chika J., Patricia Carrillo, and Martin Morgan Tuuli. 2019. "Stakeholder Management in PPP Projects: External Stakeholders' Perspective”. figshare. https://hdl.handle.net/2134/34766. 


\section{Emerald Built Environment Project and Asset Management}

\section{Stakeholder Management in PPP Projects: External Stakeholders' Perspective}

\begin{tabular}{|r|l|}
\hline Journal: & Built Environment Project and Asset Management \\
\hline Manuscript ID & BEPAM-02-2018-0048.R2 \\
\hline Manuscript Type: & Research Paper \\
\hline Keywords: & $\begin{array}{l}\text { PPP, Projects, Stakeholder Management, End-users, Construction Works, } \\
\text { Roads }\end{array}$ \\
\hline \multicolumn{2}{|c}{} \\
\hline
\end{tabular}

\section{SCHOLARONE \\ Manuscripts}




\title{
Stakeholder Management in PPP Projects: External Stakeholders' Perspective
}

\begin{abstract}
Purpose - This paper focuses on external stakeholders' perspective of stakeholder management in Public Private Partnerships (PPP) projects within the context of developing countries where public opposition to PPP projects is prevalent. The aim is to identify the key enablers to PPP projects' success from the perspective of external stakeholders.

Design/methodology/approach - Data was collected from two case studies via semistructured interviews in two PPP project locations in Nigeria. 14 external stakeholders comprising community leaders, trade unionists and human right activist participated in the research.

Findings - Five key enablers of external stakeholder management were identified. These are (1) the choice of project location; (2) transparency of the internal stakeholders; (3) timing of stakeholder engagement; (4) knowledge of PPP; and (5) relationship with internal stakeholders.

Originality/Value - External stakeholders' perspective of stakeholder management in PPP projects within the context of developing countries new to PPP has been established. The practical implications of the five enablers can be used by policy makers and industry professionals to ensure effective stakeholder management of PPP projects.
\end{abstract}

Keywords Public Private Partnership, projects, stakeholder management, end-users

Paper type - Research paper

\section{Introduction}

A Public Private Partnership (PPP) is typically an agreement between a public-sector authority and a consortium or Special Purpose Vehicle (SPV) to procure public goods and services. The essence of the consortium, according to Carrillo et al. (2006), is that no one private organisation has the in-house expertise required to fund, design, build and operate the service. The partnership arrangement combines the strength of the parties involved. The public sector's regulatory and supervisory capacity and private consortium's finance and managerial expertise are used to deliver public goods and services (Amadi et al., 2014). PPPs have delivered several successful projects, but others have experienced challenges such as stakeholder opposition, which has led to failure of some projects (El-Gohary et al., 2006). Stakeholders' opposition to PPP projects is a growing trend around the world and constitutes a major factor for the successful delivery of PPP projects (El-Gohary et al., 2006). Moreover, several reviews of PPP projects by reputable organisations and academics have 
recognised the importance of stakeholders to PPPs and recommend that stakeholders be properly consulted and managed. For example, the Organisation for Economic Cooperation and Development (OECD, 2007:18) recommended that "public authorities should ensure adequate consultation with end-users and other stakeholders including prior to the initiation of an infrastructure project".

The major causes of stakeholders' opposition to PPP projects include neglect of stakeholders' interests and concerns (El-Gohary et al., 2006) and lack of adequate processes and strategies for managing stakeholders ( $\mathrm{Ng}$ et al., 2013; Henjewele et al., 2013). A few authors have recommended strategies and processes for stakeholder management in PPP projects. However, none of these studies examined stakeholder management from the external stakeholders' perspectives to determine why they oppose PPP projects and what they consider crucial in terms of how they are engaged.

This study aims to establish key enablers that are vital in stakeholder management from the external stakeholders' perspectives. This is expected to lead to a more appropriate approach to stakeholder management in PPP projects. It contrasts two road transportation projects in Nigeria with different experiences of stakeholder management. The next section reviews literature on stakeholder theory and stakeholder management in PPP projects. Thereafter, the research methodology is discussed, findings from the case studies are presented and discussed and conclusions made.

\section{Stakeholder Theory}

The concept of stakeholders was first introduced in 1963 (Freeman, 1984). Stakeholders are referred to as those that can affect or be affected by the achievement of an organisation's objectives (Freeman, 1984). They can be internal stakeholders (those that are entrusted to use resources of the project to achieve the project's objectives) or external stakeholders (those that are affected or perceived to be affected by the project) (Newcombe, 2003; Cleland and Ireland, 2007). Within the context of this paper, internal stakeholders are the public and private sectors charged with delivering the project, while external stakeholders are members of local communities, trade unions and end-users. Since the introduction of the stakeholder theory, notable studies on stakeholders have evolved such as stakeholder theory of the corporation (Donaldson and Preston, 1995) and dynamics of stakeholders (Mitchell et al., 1997). The principles from these studies have been applied in different fields of study including construction projects (Atkin and Skitmore, 2008) to manage relationships with stakeholders and enhance success of an organisation or projects. 
The application of stakeholder principles in construction projects has become important due to the complexities of modern construction projects which create multiple stakeholders. These multiple stakeholders have different interests and concerns which could be conflicting and mismanaging these can have devastating consequences on projects such as litigations and time overrun (Chinyio and Olomolaiye, 2010). The importance of stakeholders as a key determinant to the success of projects has been recognised and has necessitated the structured management of stakeholders. The essence, according to Cleland and Ireland (2007:149), is to aid project practitioners in "identifying and understanding project stakeholders, the management of such stakeholders, and how to understand and deal with the likely parochial interests of stakeholders".

Some studies have recommended strategies for managing project stakeholders. For example, Chinyio and Akintoye (2008) recommended the use of trade-offs and negotiations for engaging stakeholders. Cleland and Ireland (2007) proposed a seven-step generic Project Stakeholder Management (PSM) process to aid project owners to manage stakeholders. Similarly, Karlsen (2002) developed six project stakeholder management steps. Other notable stakeholder management frameworks for construction projects are Bourne and Walker (2006), Sutterfield et al. (2006), and Yang et al. (2014). These studies were all within the context of traditional public procurement. However, the peculiar features of the PPP such as lengthy contract periods and responsibility sharing of project partners limit the application of these studies. In the same vein, Rwelamila (2010) stated that stakeholder management depends on, and is influenced by, the type of procurement system in use. Henjewele et al. (2013) also state that for the principles of stakeholder management to be applied in the PPP environment, there is the need to understand the unique structure of PPPs.

\section{Stakeholder Management in PPP Projects}

PPPs are characterised by long term contracts (Smyth and Edkins, 2007) and complex relationship structures. The structures of the relationships are dynamic and change at the different phases of projects (Zou et al. 2014) which result in a shift of responsibilities of the partners during and across phases (De Schepper et al., 2014). In addition, the general public, particularly for the user-fee type of PPP, are a major financial contributor to the project and thus has shaped the argument for PPP stakeholder management. A number of researchers have considered these PPP characteristics and have investigated the causes of stakeholder 
opposition and the implementation of stakeholder management and have recommended strategies for managing stakeholders. For example, Rwelamila et al. (2014) reviewed public protests and agitation against PPP projects and concluded that the major cause of these protests and agitations were due to the marginalisation of the general public. Using the principal-agent theory, the authors argue that the real first P in PPP is the public; they are supposed to be the principal and not the public sector that is the agent of the general public. They recommended a paradigm shift from the current position in which the general public is excluded to a place of inclusion where the general public is brought to the fore and be involved in decision-making in PPP schemes. The authors posit that the shift is needed owing to the fact that the current rationale and arrangement in PPP schemes encourage the marginalisation of the public. Rwelamila et al. (2014) also believe that the solution to demarginalising the public lies in understanding, linking and placing the real $P$ (public) appropriately in the stakeholder management of PPP projects and recommended that future research is required to address this. Similarly, Ahmed and Ali (2006) using solid waste management (SWM) in Bangladesh as a case study examined the role of facilitating agents in developing a public-private-people partnership (4P). They posit that the inclusion of the 4th P (people) in PPP can promote accountability, transparency in the PPP scheme and better service delivery.

To actualise the 4P concept, scholars have recommended strategies to mitigate the neglect of stakeholders and promote healthy relationships in PPP projects. For example, El-Gohary et al. (2006) developed a semantic model to capture and integrate the interests of different stakeholders at the design phase of PPP projects. Henjewele et al. (2013) proposed a multistakeholder management model consisting of five stakeholder management processes for managing stakeholders through different phases of PPP projects. $\mathrm{Ng}$ et al. (2013) proposed the $4 \mathrm{P}$ process framework for managing stakeholders in PPP projects. De Schepper et al (2014) investigated the responsibilities of the public and private sector agencies in managing stakeholders at different phases of PPP projects. The authors recommended that stakeholder management for PPPs should be approached from the dynamic dual stakeholder perspectives where the partners partake in stakeholder management at the various phases of projects. However, these studies consider stakeholder management from the internal stakeholder's perspective. This approach is considered an 'inside-out' approach by De Schepper et al. (2014). That is, stakeholder management should be looked at from within the project or organisations and not from the external environment (De Schepper et al., 2014). This 'inside-out' approach has the tendency to be limited in view or understanding of stakeholder management processes and neglect the end users - the third partner (De Schepper et al., 2014). In addition, these studies were within the context of high-income 
countries with few cases of stakeholder opposition compared to low and middle-income countries with nascent PPP experience but prevalent cases of stakeholder opposition. Rwelamila et al., (2014) reviewed stakeholder opposition to PPP projects across the world and concluded that stakeholder protests have "greater acuteness" in developing countries. Despite the high rate of stakeholder opposition, research in PPP from developing countries appears to be very low (Osei-Kyei and Chan, 2015).

The above discussion indicates that there is a need to give external stakeholders greater involvement in PPP projects and to understand the unique challenges faced on PPP projects in low and middle-income countries. This thus leads to the identification of the following research gaps:

1. What are the perceptions of external stakeholders regarding the stakeholder management process?

2. What are the enablers for the management of external stakeholders in a low and middle-income country on PPP projects? and

3. How do we place external stakeholders at the centre of stakeholder management on PPP projects?

\section{Research Methodology}

This study adopted an abductive approach because it studied existing theories related to PPP and stakeholder management and consolidated these theories where appropriate (Robson, 2011; Saunders et al., 2012). A qualitative research method was used comprising a review of literature and the examination of case studies. Proverb and Gameson (2008) suggest that case study research is relevant to industries that are driven by projects involving different types of organisations. The case study approach was used to investigate stakeholder management from the perspectives of external stakeholders. In addition, Yin (2014) suggested that case studies are ideal in research that requires no control of behavioural event and the opinions of research participants are not manipulated. This research fulfils this condition because the researchers have no control over the research participants and their actions and perceptions of stakeholder management in PPP projects.

Case Study Selection 
The case studies were carefully selected based on their relevance to the subject under consideration, and also to help define the limit to which findings could be generalised and thereby control extreme variations (Eisenhardt, 1989). The case studies are both PPP tolled road transportation projects in Nigeria but are at different project phases.

The choice of PPP tolled road transportation projects in Nigeria is based on two factors. Firstly, Nigeria is an example of a lower and middle-income country (World Bank, 2016) with increasing reliance on PPP projects and where opposition to PPP projects are most frequent (Rwelamila et al., 2014; El-Gohary et al., 2006). Secondly, PPP tolled road transportation projects are an example of a user-type PPP scheme where users pay directly for using the facility and the occurrence of stakeholders' opposition is high (El-Gohary et al. 2006). Also, road transportation projects receive wide publicity because their development usually affect a vast amount of land and property (South et al. 2015). Therefore, the case studies represent 'worst case scenario' to consider for stakeholder management in PPP projects.

The first case is a major road project. It is a 30-year concession scheme for Design, Build, Finance and Operate and Transfer (DBFOT). This project is a $49 \mathrm{~km}$ highway costing $\$ 450 \mathrm{~m}$ US. It was selected because it is one of the PPP road transportation projects in Nigeria that has generated a lot of public opposition and protests. The second case study is a bridge project; it also follows the DBFOT model with a 25-year concession period. The project consists of a bridge and approach roads which have six traffic lanes (three in each direction) for $12 \mathrm{~km}$. The project is on a greenfield site and is currently at the construction phase. In addition, the second case study was selected because it is a widely publicised major $\mathrm{road} / \mathrm{bridge}$ project but one that has been well received by the general public.

\section{Interviews}

Interviews were the main data collection method used in this study. Interviews are suited in case studies about human affairs and actions (Yin, 2014) such as stakeholder management in PPP projects that involve the interactions of people and how they relate with each other. Also, semi-structured interviews were used because of its flexibility (Robson, 2011); this gave the researchers the opportunity to seek further clarifications from the 14 interviewees indicated in Table 1. All the interviews were face to face; the averaging duration of interviews was 1 hour with the longest being 2 hours and the shortest being 45 minutes. All interviewees were directly involved in the projects and were representatives of communities and trade unions affected by the projects. The interviewees have been interacting with internal stakeholders for over three years. 
In addition, project sites were visited, and observations were recorded. Documents related to the project were obtained and analysed. The documents included minutes of meetings, environment and social impact assessment reports, stakeholder committee reports, newspaper articles, official memos, correspondences between public sector officials and the SPV, PPP policy documents, etc.

\section{Insert Table 1: Details of Case Study Interviewees}

The key themes for the semi-structured interviews were obtained from the literature and focused on (1) understanding external stakeholder's perceptions of the engagement process; (2) identifying enablers of stakeholder management; and (3) identifying practical mechanisms to promote better relationships between the internal and external stakeholders. Analysis from the interviews was conducted by identifying emerging themes from interview transcription by means of thematic analysis. Thematic analysis involves identifying patterns to make meaning and gain insight into a contemporary phenomenon (Braun and Clarke, 2006). The analysis was conducted using Miles et al. (2014) three phase data analysis: data condensation or reduction; data display; and drawing conclusions.

Data condensation involves the selection, simplification, and transformation of raw data with the aim of making sense of the data (Bryman, 2016). Data gathered in this study were condensed by coding in NVivo 10, which is efficient in data sharing and analysis and enhances accuracy and transparency of research findings (Easterby-Smith et al., 2012). Recurring or common key words and phrases from the interviewees were selected and grouped into themes. Data display is the second major phase of data analysis and involves presenting the condensed data in a compressed and formatted manner (Miles et al., 2014). Data was formatted to display emerging themes orderly and enhance easy comprehension of research findings. For example, emergent themes in each case study were arranged and grouped within the case study. Drawing and verifying conclusions is the last phase of data analysis (Miles et al., 2014). Conclusions were drawn by observing and noting themes or patterns and thereafter comparing and contrasting the emerging patterns between the case studies. For example, the interviewees considered early and continuous stakeholder engagement is vital in building and maintaining relationship with internal stakeholders. 


\section{Case Study Findings}

Findings indicate many different perceptions of external stakeholders to stakeholder management in PPP projects. External stakeholders consider these perceptions as enablers to build and maintain good relationships among the stakeholders and the success of PPP projects.

\section{Project Location}

Findings indicate that the project location in both case studies was significant in external stakeholders' perception of the public and private sectors. The first case study, on a brownfield site, was not well received by the communities and road users because they felt unjustly treated. Interviewee E1 stated that:

"They only added a lane to the existing road and asked us to pay which is not fair. The addition of a lane has not reduced traffic as planned. The toll is not right and should be dismantled. They should develop an alternative route such as the coastal road to link with the mainland".

This perception of unfair treatment led to several protests and agitation against the project.

For the second case study, a greenfield project, members of the communities saw the project as a major relief to their pain and suffering in commuting in and around their communities, hence their warm reception to internal stakeholders and the project. According to Interviewee C2:

"They all came down to the community to meet us, they indicated their interest in the project, we approved them because it is a welcome development... We welcomed all of them because we know with that our community will be developed. The community is an ordinary rural and agrarian community but with this type of project, with time it will be a city. So it is a welcome development".

Thus, the second case study had an opposite outcome to the first case allowing comparisons and lessons to be learned.

\section{Transparency of Internal Stakeholders}

Interviewees in both case studies acknowledged transparency as key in ensuring a healthy relationship with the public and private sectors and continued support for PPP projects. However, the perception of the transparency varied significantly in both case studies. 
In the first case study, interviewees generally perceived the public and private sector as not transparent. For example, Interviewee $\mathrm{C} 1$ remarked that:

"Government needs to be transparent. There is a lot of secrecy with their operations".

Interviewees considered that 'truth, honesty, forthrightness' as indicators and a measure of transparency, which were lacking during their interactions with internal stakeholders. This led interviewees to treat internal stakeholders with 'suspicion' and this undermined their support for PPP projects. For example, Interviewee B1 stated that:

"So when you are having engagement and there are mutual distrust and suspicion, of course you can only expect things like sabotage by different groups".

The majority of the interviewees in the second case study believed that the public and private sectors had been truthful and honest in dealing with them. For example, Interviewee D2 remarked that:

"What has been the key between our relationship and government and companies involved in the project is that there is no deceit; we don't come to them with deceit and they have never deceived us as well. When there is trust, there is always success".

However, property owners do not completely see the public sector as honest in paying compensation because of the delay in payment. Interviewee E2 stated:

"The government has not been forthright in whatever they are doing.... They have not been forthright in paying of compensation. People are becoming suspicious".

As a result, property owners demonstrated against the government.

\section{Timing of Stakeholder Engagement}

The timing of the stakeholder management is considered from two perspectives: early stakeholder engagement; and continuous engagement. The findings indicate that the timing of stakeholder management boosted or ebbed the confidence of the external stakeholders in the stakeholder engagement exercise. Interviewees of the first case study were dissatisfied with the engagement because they considered it too late. Interviewees believed that late stakeholder engagement 'cannot be considered engagement' and 'not good enough'. For example, Interviewee D1 stated that: 
"The people were essentially engaged only towards the end of the thing, and the engagement was because government could not continue, you don't call that engagement.

With the conception of the road, we were not carried along at all".

In addition, external stakeholders expressed the need to have continuous stakeholder engagement due to the duration of the toll road.

However, interviewees of the second case study generally believed that the internal stakeholders started engaging them early. For example, Interviewee G2 stated:

"They came early enough, they didn't wait to be invited, they came on their own".

The external stakeholders were pleased with the early engagement and commended internal stakeholders for being proactive. For example, Interviewee B2 remarked:

"These people came early enough, I commend them for that".

It was generally acknowledged by the interviewees in both case studies that stakeholder engagement should commence from the conception and planning phases of projects.

Knowledge of PPP

PPP is at its infancy in Nigeria and the interviewees admitted their lack of knowledge and awareness of the PPP scheme. Findings however indicate that external stakeholders had varied knowledge of the PPP scheme in both case studies and it affected their reception of internal stakeholders. In the first case study, the findings indicate external stakeholders' lack of awareness and ignorance of the PPP scheme. According to Interviewee A1:

"We don't know PPP; I think we are the first to start PPP in Nigeria".

While for the second case study, the findings show that external stakeholders had a fair amount of knowledge of the PPP project. For example, during interviewees they expressed knowledge of the project and gave details of duration of the concession, and how tolls will be collected. External stakeholders' knowledge of the PPP project was enhanced by a series of meetings where information was disseminated as highlighted by Interviewee $\mathrm{H} 2$ :

"They opened up how far they have gone. They televised it on video system place on a blank board. So we witnessed how far they have gone, how the roads from the swampy area, how the roads will be hung and how motorists will be travelling on it". 


\section{Relationship with Internal Stakeholders}

It was generally acknowledged by interviewees in both case studies that a good relationship between the internal and external stakeholders is vital for the success of PPP projects. For example, Interviewee A2 stated that:

"There must be relationship between whoever is constructing anything with the community".

In addition, the interviewees believed in making PPP projects 'all inclusive'; external stakeholders also see the PPP projects as 'our project' and this will guarantee the support of their support and consequently enhance the success of PPP projects. Interviewee D1 sums it up thus:

"If we had been carried along very well and if it had been all inclusive and it's our project, nobody would come and talk about cancelling it and all of those things".

The summary of findings from the case studies is presented in Table 2.

\section{Insert Table 2: Summary of the findings}

\section{Discussion}

It has become imperative to understand stakeholder engagement in PPP projects from the external stakeholders' perspective. This research has identified five key stakeholder engagement enablers: project location; transparency of internal stakeholders; timing of stakeholder engagement; knowledge of PPP; and relationship with internal stakeholders.

Findings suggest that the PPP project location and the perception of its importance to external stakeholders give impetus to external stakeholders to accept or reject the project. This finding provides a new insight and explanation of how external stakeholders' reception to internal stakeholders in PPP schemes vary from project to project. No previous research work has focused on how project location can influence project success. This finding has practical implications on how policy makers decide on which project to execute and how the external stakeholders should be engaged. A thorough needs assessment is therefore crucial before choosing a project. In addition, choosing a project that is acceptable to external stakeholders provides a good platform to ensure a successful stakeholder engagement on PPP projects.

The findings also highlight the effect perceived lack of transparent PPP processes can have: suspicion; distrust; and low confidence in the internal stakeholders. Transparency of PPP 
projects and stakeholder engagement is therefore a key requirement for ensuring the buy-in of external stakeholders. Bickerstaff et al., (2002) support this stating that transparency of any stakeholder engagement exercise is fundamental to its success. Also, findings show external stakeholders calibrate the transparency based on internal stakeholders' ability to keep to promises, be truthful and without deceit. The practical implication of this is that internal stakeholders should adopt openness and full disclosure of project information rather than 'half-truths' to boost positive perception and confidence in PPP projects.

In terms of the timing of stakeholder engagement, the findings show that early or late stakeholder engagement impacts on building trust and confidence. Stakeholder engagement, at the conception and planning phase of PPP projects, as suggested by external stakeholders, helps to address the question "how early should stakeholder engagement commence?". Early engagement of external stakeholders helps to identify all stakeholders, capture their concerns and integrate them early into the project to avoid "seeking them later as protests groups" (Kumaraswamy et al., 2015:128). Also, early stakeholder engagement on PPP projects helps facilitate projects that meet stakeholders' needs (El-Gohary, et al., 2006). The practical implication is that internal stakeholders should allocate time for specific stakeholder engagement activities. These should not be limited to the early phase of PPP project but throughout the project lifecycle. This is particularly important because of the external influences such as inflation and currency fluctuations which could negatively impact on stakeholder's support for the project.

External stakeholders' perception to PPP projects are based on their knowledge of PPP schemes. For example, Levy (1996) noted that public lack of knowledge of PPP was mainly responsible for their opposition of PPP transportation schemes, which resulted in the cancellation of projects. Findings show that internal stakeholders can enhance the capacity and knowledge of the external stakeholders by organising workshops and lectures on PPP. This finding is consistent with Henjewele et al's. (2013) recommendation for the training of the external stakeholders on the anatomy of the PPP scheme. Educating external stakeholders on the PPP scheme should not be a one-off exercise but done throughout the PPP project. This targets new stakeholders that might be identified during the course of the project. The implication of this finding is that the stakeholder management process should include capacity building activities targeting both internal stakeholders (to train them to be educators) and external stakeholders (to provide them with knowledge of PPP process and projects).

Marginalisation of external stakeholders has been identified as the main cause of stakeholders' opposition to PPP projects (Rwelamila et al., 2014). Building partnerships 
between the internal and external stakeholders are recommended as panacea to demarginalise the public (Henjewele et al., 2013). Evidence from this research indicates external stakeholders' willingness to support PPP projects if the project is 'theirs' and they become co-owners of the project. This finding fits into the citizen's power category of Arnstein's (1969) 'ladder of citizen participation' where the public are no longer on the fringes but partake in decision-making. In addition, this finding implies that policy makers need to understand the power of the public and treat them as co-owners of PPP projects, particularly if they are the main source of revenue and financial contributors to the project.

\section{Limitations of the Research}

Whilst the findings have provided an insight into improving stakeholder engagement, there are limitations to the study in terms of scope. The research is limited to two case studies in Nigeria and is therefore relevant to that context; different geographical regions may have different cultural contexts. The research is also limited to the road transportation sector and other sectors' peculiarities are not accommodated. Hence, this study should be replicated to other sectors such as education, health, energy, etc. The findings will help enhance the generalizability of stakeholder management in PPP projects.

\section{Conclusions}

Stakeholders have an overwhelming influence on the outcome of PPP projects. Several PPP projects, particularly those in low and middle-income countries have failed due to stakeholders' opposition. This has made it imperative to understand the role of external stakeholders and how they are managed through the different PPP project phases.

Previous research on stakeholder management proposed strategies for managing stakeholders within the PPP context. However, these generally did not focus on external stakeholders. This study aimed to establish key enablers that are vital in stakeholder management from the external stakeholders' perspectives. This was achieved by adopting a case study approach for two road transportation projects in Nigeria. Semi-structured interviews were used to understand external stakeholder's perceptions of the engagement process, identify enablers of stakeholder management, and identify practical mechanisms to promote better relationships between the internal and external stakeholders. This study adds to the existing body of knowledge but acknowledges that this is based on a single country study. 
The findings identified five key enablers to the success to PPP road transportation projects. From the external stakeholders' perspective these are: project location; transparency of internal stakeholders; timing of stakeholder engagement; knowledge of PPP; and relationship with the internal stakeholders. These enablers complement each other, and have poignant implications on the success of the stakeholder management process. The implications are: (1) a requirement for a thorough needs assessment for the project as highlighted by the project location enabler; (2) the need for full disclosure of project information as indicated by the transparency enabler; (3) the need to have a plan for stakeholder engagement activities throughout the project process to address the timing enabler; (4) the need to build capacity both amongst both internal and external stakeholders to improve knowledge of PPP; and (5) the need for policy makers to treat external stakeholders as co-owners of PPP projects. Whilst not an exhaustive list, addressing these enablers should lead to a more partnership-style engagement that not only focuses on the public private relationship but on the public-public relationship.

\section{References}

Ahmed, S.A. and Ali, S.M. (2006), "People as Partners: Facilitating People's Participation in Public-Private Partnerships for Solid Waste Management", Habitat International, Vol. 30 No. 4, pp. $781-796$.

Amadi, C., Carrillo, P., Tuuli, M. (2014), "Stakeholder management in public private partnership projects in Nigeria: towards a research agenda, in Association of Researchers in Construction 2014 Proceeding of 30th Annual ARCOM Conference in Portsmouth, United Kingdom, Association of Researchers in Construction Management, pp. 423-432.

Atkin, B. and Skitmore, M. (2008), Editorial: "Stakeholder management in construction", Construction Management and Economics, Vol. 26 No.6, pp. 549-552.

Arnstein, S.R. (1969), "A ladder of citizen participation", Journal of the American Institute of Planners, Vol. 35 No.4, pp. 216-224.

Braun, V. and Clarke, V. (2006), "Using thematic analysis in psychology", Qualitative Research in Psychology, Vol. 3 No 2, pp. 77-101. 
Bickerstaff, K., Tolley, R. and Walker, G. (2002), "Transport planning and participation: The rhetoric and realities of public involvement", Journal of Transport Geography, Vol. 10 No.1, pp. 61-73.

Bourne, L. and Walker, D.H. (2006), "Using a visualising tool to study stakeholder influence two Australian examples", Journal of Project Management, Vol. 37 No.1, pp. 5-21.

Bryman, A. (2016), Social Research Methods. $5^{\text {th }}$ Ed., Oxford University Press, United Kingdom.

Carrillo, P.M., Robinson, H.S., Anumba, C.J. and Bouchlaghem, N.M. (2006), "A knowledge transfer framework: The PFI context", Construction Management and Economics, Vol. 24 No.10, pp.1045-1056.

Chinyio, E. \& Akintoye, A. (2008), "Practical Approaches for Engaging Stakeholders: Findings from the UK", Construction Management and Economics, Vol. 26 No.6, pp. 591599.

Chinyio, E. and Olomolaiye, P. (2010), "Introducing stakeholder management", in Chinyio, E. and Olomolaiye, P. (Ed.), Construction Stakeholder Management, Wiley-Blackwell, Chichester.

Cleland, D.I. and Ireland, L.R. (2007), Project management: Strategic Design and Implementation 5th Ed., McGraw- Hill, New York; London.

De Schepper, S., Dooms, M. \& Haezendonck, E. (2014), "Stakeholder dynamics and responsibilities in Public-Private Partnerships: A mixed experience", International Journal of Project Management, Vol. 32 No.7, pp. 1210-1222.

Donaldson, T., and Preston, L. E. (1995), "The stakeholder theory of the corporation: Concepts, evidence, and implications", Academy Management Review, Vol. 20 No.1, pp. 6591.

Easterby-Smith, M., Thorpe, R. and Jackson, P. (2012), Management Research: An Introduction. $4^{\text {th }} \mathrm{Ed}$., SAGE, London.

Eisenhardt, K. M. (1989), "Building theories from case study research", Academy of Management Review, Vol.14 No. 4, pp. 532-550. 
El-Gohary, N., Osman, H. \& El-Diraby, T. (2006), "Stakeholder management for Public Private Partnerships", International Journal of Project Management, Vol. 24 No. 7, pp. 595604.

Freeman, R. E. (1984), Strategic Management: A Stakeholder Approach, Pitman, Boston, (MA); London.

Henjewele, C., Fewings, P. \& Rwelamila, P.D. (2013), "De-marginalising the public in PPP projects through multi-stakeholders management", Journal of Financial Management of Property and Construction, Vol. 18 No. 3, pp. 210-231.

Karlsen, J.T. (2002), "Project stakeholder management", Engineering Management Journal, Vol. 14 No. 4, pp. $19-24$.

Kumaraswamy, M., Zou, W. and Zhang, J. (2015), "Reinforcing relationships for resilience by embedding end-user 'people' in public-private partnerships", Civil Engineering and Environmental Systems, Vol. 32 No. 1-2, pp. 119-129.

Levy, S.M. (1996), Build, Operate, Transfer: Paving the Way for Tomorrow's Infrastructure, Wiley, Chichester.

Miles, M.B., Huberman, A.M. and Saldaña, J. (2014), Qualitative Data Analysis: A Methods Sourcebook, Sage Publications, California.

Mitchell, R.K., Bradley, R.A. and Wood, D.J. (1997), "Toward a theory of stakeholder identification and salience: defining the principle of who and what really counts", Academy of Management Review, Vol. 22 No. 4, pp. 853-85.

Newcombe, R. (2003), "From client to project stakeholders: a stakeholder mapping approach", Construction Management and Economics, Vol. 21 No. 8, pp. 841-848.

Ng, S.T., Wong, J.M. \& Wong, K.K. (2013), "A public private people partnerships (P4) process framework for infrastructure development in Hong Kong", Cities, Vol. 31, pp. 370381.

Organisation for Economic Cooperation and Development (OECD) (2007), OECD Principles for Private Sector Participation in Infrastructure, Paris.

Osei-Kyei, R. and Chan, A.P., (2015), "Review of studies on the Critical Success Factors for Public-Private Partnership (PPP) projects from 1990 to 2013", International Journal of Project Management, Vol. 33 No.6, pp.1335-1346. 
Proverbs, D. and Gameson, R. (2008), "Case study research”, in Knight, A. and Ruddock, L. (Ed.), Advanced Research Methods in the Built Environment, John Wiley and Sons, Chichester, pp. 99-110.

Robson, C. (2011), Real World Research: A Resource for Users of Social Research Methods in Applied Settings, Wiley, Chichester.

Rwelamila, P.D. (2010), "Impact of procurement on stakeholder management”, in Chinyio, E. and Olomolaiye, P. (Ed.), Construction Stakeholder Management, Wiley-Blackwell, Chichester, pp.193-215.

Rwelamila, P.D., Fewings, P. \& Henjewele, C. (2014), "Addressing the missing link in PPP Projects: What constitutes the public?", Journal of Management in Engineering, Vol. 31 No. 5, pp. 1-9.

Saunders, M., Lewis, P. \& Thornhill, A. (2012), Research Methods for Business Student, Pearson Education Limited, England.

South, A.J., Levitt, R.E. and Dewulf, G. (2015), "Dynamic stakeholder networks and the governance of PPPs", in 2015 Proceedings of the 2nd International Conference on PublicPrivate Partnerships, Austin, Texas, U.S.A, pp. 1-17.

Smyth, H. and Edkins, A. (2007), "Relationship management in the management of PFI/PPP projects in the UK", International Journal of Project Management, Vol. 25 No. 3, pp. 232-240.

Sutterfield, J., Friday-Stroud, S., and Shivers-Blackwell, S. (2006), "A case study of project and stakeholder management failures: lessons learned", Project Management Journal, Vol. 37 , No. 5, pp. 26-35.

World Bank Group (2016), 2016 World Development Indicators, World Bank Group, Washington.

Yang, R.J. and Shen, G.Q. (2014), "Framework for stakeholder management in construction projects", Journal of Management in Engineering, Vol. 31 No. 4, pp. 1-14.

Yin, R.K. (2014), Case Study Research: Design and Methods, $5^{\text {th }}$ Ed., Sage, Los Angeles.

Zou, W., Kumaraswamy, M., Chung, J. and Wong, J. (2014), "Identifying the critical success factors for relationship management in PPP projects", International Journal of Project Management, Vol. 32 No. 2, pp. 265-274. 
Table 1: Details of Case Study Interviewees

\begin{tabular}{|l|l|l|}
\hline Code & Stakeholder Identity & Stakeholder Position \\
\hline & \multicolumn{2}{|c|}{ Case Study 1 } \\
\hline A1 & Representative of Community A & Community chief \\
\hline B1 & Representative of Community B & $\begin{array}{l}\text { Chairman of a community } \\
\text { association }\end{array}$ \\
\hline C1 & Representative of Community C & Community leader \\
\hline D1 & Representative of Community D & Community youth leader \\
\hline E1 & Representative of Community E & Community leader \\
\hline F1 & Business Community & Business Owner \\
\hline & \multicolumn{2}{|c|}{ Case Study 2 } \\
\hline A2 & Representative of Community A & Community Chief \\
\hline B2 & Representative of Community B & Community Leader \\
\hline C2 & Representative of Community C & $\begin{array}{l}\text { Member of the community } \\
\text { committee on the project }\end{array}$ \\
\hline D2 & Representative of Community D & $\begin{array}{l}\text { Member of the community } \\
\text { committee on the project }\end{array}$ \\
\hline E2 & Representative of Community E & $\begin{array}{l}\text { Member of the community } \\
\text { committee on the project }\end{array}$ \\
\hline F2 & Trade Union A & Chairman \\
\hline G2 & Trade Union B & Chairman \\
\hline H2 & Human Rights Activist & Chairman \\
\hline & Total & $\mathbf{1 4}$ \\
\hline
\end{tabular}


Table 2: Summary of the findings

\begin{tabular}{|c|c|c|}
\hline Enablers/outcome/perception & Case study 1 & Case study 2 \\
\hline \multirow{2}{*}{$\begin{array}{l}\text { Project Location } \\
\text { Outcome/perception }\end{array}$} & $\begin{array}{l}\text { Brownfield (addition of lanes } \\
\text { to existing road) }\end{array}$ & Greenfield \\
\hline & $\begin{array}{l}\text { Feeling of unfair treatment } \\
\text { and little positive impact of the } \\
\text { project }\end{array}$ & $\begin{array}{l}\text { Seen as a good } \\
\text { development and one that } \\
\text { will be economically } \\
\text { beneficial }\end{array}$ \\
\hline \multirow[t]{2}{*}{$\begin{array}{l}\text { Transparency of Internal } \\
\text { Stakeholders }\end{array}$} & Lack of transparency & $\begin{array}{l}\text { Most interviewees see } \\
\text { engagement as } \\
\text { transparency }\end{array}$ \\
\hline & $\begin{array}{l}\text { Distrust, suspicion and } \\
\text { protests }\end{array}$ & $\begin{array}{l}\text { Trust, confidence and } \\
\text { suspicion by others }\end{array}$ \\
\hline \multirow{2}{*}{$\begin{array}{l}\text { Relationship with internal } \\
\text { stakeholders } \\
\text { Outcome/perception }\end{array}$} & Lack of partnership & $\begin{array}{l}\text { There is some evidence of } \\
\text { partnership but not to the } \\
\text { level of co-ownership }\end{array}$ \\
\hline & $\begin{array}{l}\text { External stakeholders want to } \\
\text { be co-owners of projects. }\end{array}$ & $\begin{array}{l}\text { See partnership as } \\
\text { essential. }\end{array}$ \\
\hline \multirow{2}{*}{$\begin{array}{l}\text { Timing of engagement } \\
\text { Outcome/perception }\end{array}$} & Late, delayed. & Timely \\
\hline & $\begin{array}{l}\text { Seen as "medicine after } \\
\text { death". Ineffective and } \\
\text { unsatisfactory. }\end{array}$ & $\begin{array}{l}\text { Boosted external } \\
\text { stakeholders' confidence }\end{array}$ \\
\hline \multirow{2}{*}{$\begin{array}{l}\text { Knowledge of PPP } \\
\text { Outcome/perception }\end{array}$} & $\begin{array}{l}\text { Lack of knowledge and } \\
\text { understanding of PPP }\end{array}$ & Fair knowledge of PPP \\
\hline & $\begin{array}{l}\text { Disputes and disruption of the } \\
\text { project }\end{array}$ & $\begin{array}{l}\text { Comfortable with expected } \\
\text { project outcomes }\end{array}$ \\
\hline
\end{tabular}

